\title{
A Method to Improve Leaf Succulence Quantification
}

\author{
André Mantovani \\ Laboratório de Anatomia Fisiológica; Departamento de Botânica; Instituto de Biologia; Universidade Federal do \\ Rio de Janeiro; Centro de Ciências da Saúde; Bloco A; 21949-900; Rio de Janeiro; RJ; Brasil.
}

\begin{abstract}
Leaf succulence has important physiological and ecological implications. Currently it is quantified by Delf's index (fresh weight/leaf area) and fresh weight/ dry weight ratio. Both indeces are reconsidered and a new index is proposed. Shade and sun leaves from terrestrial, hemiepiphytic and epiphytic aroids were studied. Delf's formula, which does not consider dry weight, overestimated leaf succulence. As fresh weight / dry weight ratio $(f w / d w)$ does not consider leaf area, plants with the same fw / dw ratio were more than five times different in area. The last case was only possible with a decrease in surface / volume ratio and a increase of mesophyll thickness, components not measured by $\mathrm{fw} / \mathrm{dw}$ ratio. The new index proposed here, which takes into consideration dry weight and leaf area, showed a high correlation to mesophyll thickness.
\end{abstract}

Key words: leaf succulence; water relations; leaf anatomy; Araceae; ecophysiology

\section{INTRODUCTION}

Succulence is often seen as an anatomical trait common to plants with a high development of a water storage tissue (Kluge and Ting, 1978), in one or various plant organs (Levitt, 1970). Succulent tissues possess large cells with thin walls, few chloroplasts and a large vacuole. They may be present externally as a simple or multiple epidermis (Haberlandt, 1928), or also internally as a hypoderm (Kaul, 1977) or as ground parenchyma (Coutinho, 1962).

Different indices and morphological measurements have been used in the literature as an attempt to quantify succulence. Delf (1912) was the first to propose a "degree of succulence" (S), obtained by the ratio between saturating water content and surface area. Walter (1926) used the index called "surface expansion", which is similar to the inverse of Delf's formula. Years later, the theme was discussed by Kluge and Ting (1978) who proposed "mesophyll succulence" index (Sm), considering that previous indices understimated the capacity of photosynthesing cells to store water. "Sm" is the ratio water content/chlorophyll content of the chlorenchymatic tissue. However the separation of the photosynthetic tissue from the water parenchyma is operationally difficult to perform on thin leaves (Kluge \& Ting 1978), which restricts the applicability of this index to extremaly thick leaves.

Structural indices could also be used to this purpose, although providing only an indirect measure (Osmond et al., 1989). Winter et al. (1983) found a good correlation between mesophyll thickness and CAM activity in orchids. Mesophyll thickness has been often used to express the environmental effect on leaf anatomy, possibly due to the consequent reduction of the surface/volume ratio. For instance, Nobel and collaborators (Nobel, 1981; Nobel et al., 1975) used the mesophyll area per leaf area index (Ames/A), as a reduction factor in $\mathrm{CO}_{2}$ diffusion in the liquid phase, which had also been considered as a good succulence quantification (Osmond et al., 1989).

Currently, the succulence degree has been more frequently obtained through the methods of Delf (Kaul, 1977; DeSanto et al., 1983) and Kluge and Ting (DeSanto et al., 1983). However, Zotz and Winter (1994), Franco et al. (1996) and Hoolbrook and Putz (1996) analysed the succulence as a function of the dry weight through the ratio fresh weigh /dry weight (FW/DW). 
Larcher (1986) stressed that a plant would be more drought resistant if it possessed a high water storage capacity, in addition to low transpiration rates. A possible way to reduce transpiration is by decreasing leaf area (Smith, 1978). In this case, leaf thickness should increase in order to allocate and maintain the same water level. Thus, leaves with the same amount of water are likely to differ in regard to area and structure. In this sense, succulence should be considered as the capacity to store water per unit of leaf area. Thus, one should use Delf's index to quantify leaf succulence, as proposed by Larcher (1986). However, Delf (1912) did not consider dry weight as a component of leaf fresh weight, before quantifying succulence. Similarly, the applicability of the ratio FW/DW as a structural succulence index is limited, as it does not consider leaf area.

This work proposes a simple method that combines water storage capacity, dry weight and leaf area simultaneously. This stands as an alternative to Delf's index, which disregards dry weight as a descriptive tool, and to the FW/DW method, which disregards leaf area.

\section{MATERIALS AND METHODS}

Plants belonging to the Araceae family (Table I) were chosen, since they show distinct life forms, which means distinction in water availability. Using young and adult plants, three different habits (terrestrial, hemiepiphytic and epiphytic) could be assessed, even in a same species (e.g., Philodendron alternans). These plants were found in low-montane areas of Brazilian Atlantic Forest at Reserva Botânica das Águas Claras (22 $\left.31^{\prime} \mathrm{S} ; \quad 42^{0} 30^{\prime} \mathrm{W}\right)$ (Silva Jardim County, Rio de Janeiro State). The average annual precipitation at the study area is $2223 \mathrm{~mm}$ (Mantovani, 1997).Young shade and sun leaves of adult plants were measured. Ten leaves from ten different individuals were collected, immediately placed in sealed plastic bags and taken to the laboratory. The leaves were excised at the proximal part of their petioles and left in
Beckers, inside moistened plastic bags, for $12 \mathrm{~h}$ at $4^{0} \mathrm{C}$ (Araus \& Hogan, 1994) to allow water imbibition. Afterwards, each leaf was reweighed and the value recorded as maximum fresh weigh (MFW). Leaf shape was then drawn on paper to calculate the leaf area (A). Finally leaves were oven-dried for two days under $60^{\circ} \mathrm{C}$, a period pre-determined as sufficient to obtain its constant dry weight (DW). Succulence was then calculated using Delf's (1912) formula (MFW/A) and the ratio MFW/DW. The alternative formula proposed, hereforth called "leaf succulence" (LS), is:

$$
\mathrm{LS}=\underline{\mathrm{MFW}-\mathrm{DW}}
$$

(A)

Mesophyll thickness was measured in fresh leaves, following current methods (Vieira, 1995). For comparisons between Delf's index (Delf, 1912) and the one proposed here, a t-test was used.

\section{RESULTS AND DISCUSSION}

The lack of correlation between Delf' sindex and dry weight is seen in figure $1 \mathrm{~A}$. Leaves with the same water storage capacity had distinct dry weight values, which is disregarded by Delf's formula. Additionally, there was a poor correlation between maximum fresh weight and dry weight of leaves studied (figure 1B). The importance of accounting for dry weight consideration in leaf succulence quantifications is represented by significant differences $(P<$ 0,05 ) between values using Delf's (4) formula and the leaf succulence (LS) index. It means that Delf's index could overestimate leaf succulence.

From a structural perspective, if two leaves have the same amount of water, the more succulent would be the one allocating water in a smaller area. Figure 1C shows the lack of correlation between leaves with the same MFW/DW but with distinct areas $\left(\mathrm{R}^{2}=0.033\right)$ which points out to the importance of leaf area in succulence measurements. Table 1 confirms this 
observation by showing that leaves more than five times different in area (e.g., young and adult plants of Anthurium longifolium (Hoff.) Godow) had the same storage capacity. This is only possible with a decrease in the
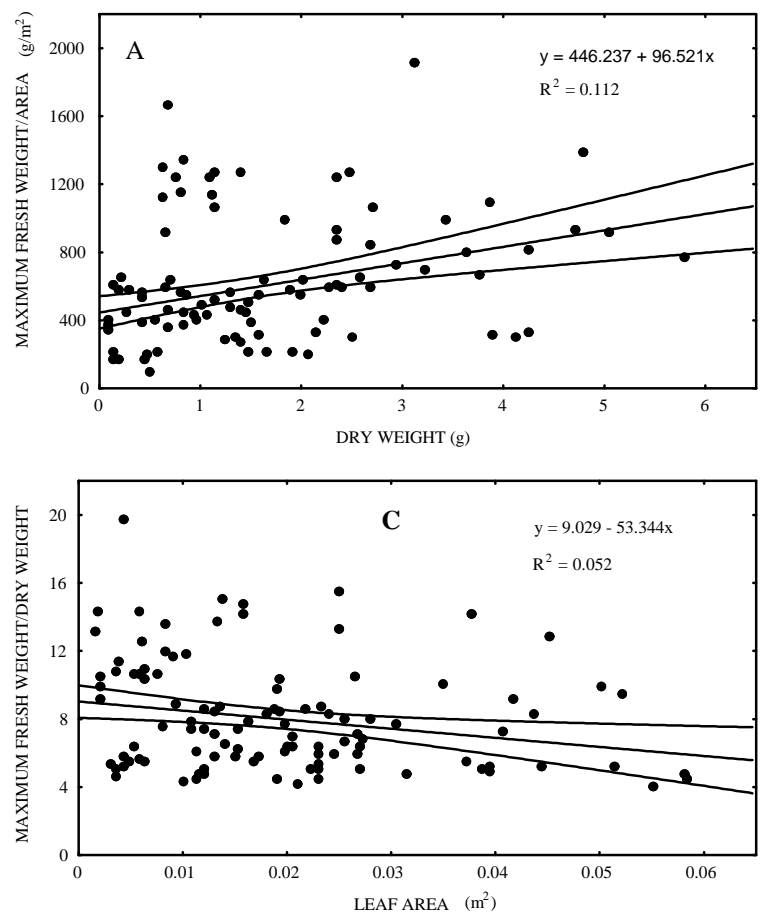

surface/volume ratio, which increases mesophyll thickness (Table I). This is best shown in figure 1D. Considering leaf area, leaf succulence index (LS) automatically takes
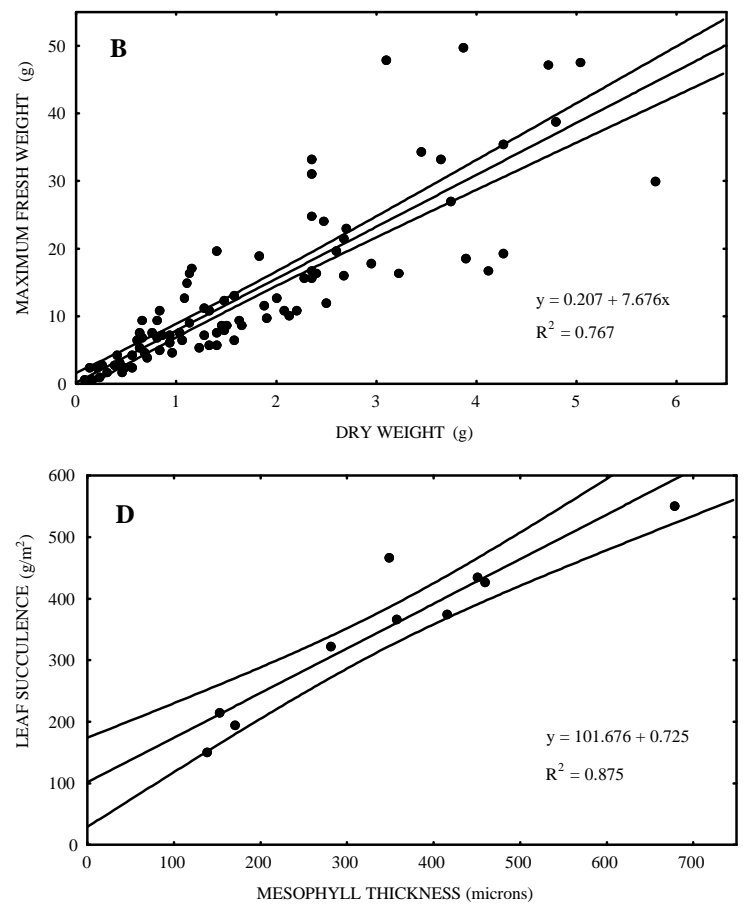

Figure 1 - Correlations between different succulence indeces and leaf traits. A - Linear regression between Delf's index (1912) and dry weight, showing low $\mathrm{R}^{2}$. B - Correlation between fresh weight and dry weight. Note increase in the dispersion of data with highers values of fresh weight. C - Linear regression between maximum fresh weight/dry weight (MFW/DW) and leaf area. D - Linear regression between leaf succulence (LS) and mesophyll thickness, showing good correlation.

into account variations in surface/volume. As a consequence, a very good correlation was found between the leaf succulence index and mesophyll thickness $\left(\mathrm{R}^{2}=0.875\right)$.

Although a structural feature, succulence has clear ecophysiological implications (Lüttge \& Smith, 1984). It minimizes the effects of drought caused by salt (Flowers, 1986), temperature (Kluge \& Ting, 1978) and water (Fahn \& Cutler, 1992) stresses. As transpiration is reduced through a smaller leaf area (Smith, 1978; Hopkins, 1995) and a larger volume (Gates 1968; Kluge \& Ting, 1978), both structural components should be also accounted for in succulence measurements, which can be done through the formula proposed here. 
Table I. List of species, with ages, life forms and light conditions of their habitats. Leaf area and mesophyll thickness are presented for comparison with the different succulence indices. Data are means \pm SD ( $n=10$ to all, except mesophyll thickness: $n=25$ ). Different letters indicate significant differences between Delf's and leaf succulence (LS) indices $(P<0,05)$. Species are: Rhodospatha oblongata Poeppig, Anthurium longifolium (Hoff.) Godow, Philodendron alternans Schott. and Philodendron crassinervium Lindley.

Abbreviations: A=adult; E=epiphyte; $\mathrm{Sh}=$ shade; $\mathrm{Su}=$ sun; $\mathrm{T}=$ terrestrial; $\mathrm{Y}=\mathrm{young} ; 1^{\mathrm{ry}} \mathrm{H}=$ primary hemiepiphyte; $2^{\text {ry }} \mathrm{H}=$ secondary hemiepiphyte.

\begin{tabular}{|c|c|c|c|c|c|c|c|c|}
\hline Specie & Age & $\begin{array}{c}\text { Life } \\
\text { Form }\end{array}$ & Light & $\begin{array}{c}\text { Leaf } \\
\text { Area } \\
\left(10^{-2} \mathrm{~m}^{2}\right) \\
\end{array}$ & $\begin{array}{c}\text { Mesophyll } \\
\text { thickness } \\
(\mu \mathrm{m})\end{array}$ & $(\mathrm{FW} / \mathrm{DW})$ & $\begin{array}{c}\text { Delf's Index: } \\
\text { Degree of } \\
\text { Succulence (S) }\end{array}$ & $\begin{array}{c}\text { Leaf } \\
\text { Succulence } \\
\text { (LS) } \\
\end{array}$ \\
\hline \multirow[t]{3}{*}{$R$ _oblongata } & Y & $T$ & $\mathrm{Sh}$ & $0.4+0.1$ & $136.2+73$ & $5.5+0.5$ & $1837+198^{\mathrm{a}}$ & $150.1+14.5^{b}$ \\
\hline & A & $2^{\mathrm{ry}} \mathrm{H}$ & Sh & $5 \pm 1$ & $153.0 \pm 7.0$ & $4.9 \pm 0.4$ & $270.1 \pm 54.1^{\mathrm{a}}$ & $214.9 \pm 39.8^{\mathrm{a}}$ \\
\hline & A & $2^{\mathrm{ry}} \mathrm{H}$ & $\mathrm{Su}$ & $2 \pm 0.5$ & $170.4 \pm 5.6$ & $4.6 \pm 0.3$ & $240.6 \pm 67.1^{\mathrm{a}}$ & $187 \pm 50.3^{\mathrm{b}}$ \\
\hline \multirow[t]{3}{*}{ A. longifolium } & $\mathrm{Y}$ & $\mathrm{E}$ & Sh & $0.4 \pm 0.1$ & $280.8 \pm 26.2$ & $6.8 \pm 0.9$ & $379.3 \pm 62.9^{\mathrm{a}}$ & $322.9 \pm 53.6^{\mathrm{b}}$ \\
\hline & A & $\mathrm{E}$ & Sh & $1 \pm 0.3$ & $354.6 \pm 50.3$ & $6.9 \pm 0.9$ & $430.2 \pm 39.9^{\mathrm{a}}$ & $366.6 \pm 31.0^{\mathrm{b}}$ \\
\hline & A & $\mathrm{E}$ & $\mathrm{Su}$ & $2 \pm 0.5$ & $458.4 \pm 21$ & $5.9 \pm 0.5$ & $514.8 \pm 96.9^{\mathrm{a}}$ & $428.2 \pm 84.8^{\mathrm{b}}$ \\
\hline \multirow[t]{3}{*}{ P.alternans } & $\mathrm{Y}$ & $\mathrm{E}$ & Sh & $0.4 \pm 0.2$ & $448.8 \pm 43.4$ & $11.3 \pm 1.5$ & $478.8 \pm 99.8^{\mathrm{a}}$ & $435.9 \pm 91.6^{\mathrm{b}}$ \\
\hline & $\mathrm{A}$ & $1^{\mathrm{ry}} \mathrm{H}$ & $\mathrm{Sh}$ & $2 \pm 0.6$ & $348 \pm 10.3$ & $8.4 \pm 0.2$ & $530.3 \pm 49.1^{\mathrm{a}}$ & $467.3 \pm 45.5^{\mathrm{b}}$ \\
\hline & A & $1^{\mathrm{ry}} \mathrm{H}$ & $\mathrm{Su}$ & $3 \pm 0.6$ & $675.7 \pm 38.2$ & $6.5 \pm 0.9$ & $659.9 \pm 60.5^{\mathrm{a}}$ & $556.1 \pm 41.5^{\mathrm{a}}$ \\
\hline \multirow[t]{3}{*}{ P. crassinervium } & $\mathrm{Y}$ & E & $\mathrm{Sh}$ & $1 \pm 0.2$ & $273 \pm 12.4$ & $12.0 \pm 3.6$ & $1062 \pm 360^{\mathrm{a}}$ & $970.0 \pm 342.4^{\mathrm{a}}$ \\
\hline & $\mathrm{A}$ & E & Sh & $3 \pm 0.1$ & $291.2 \pm 7.7$ & $11.7 \pm 2.6$ & $1048 \pm 180^{\mathrm{a}}$ & $957.3 \pm 182.2^{\mathrm{a}}$ \\
\hline & $\mathrm{A}$ & $\mathrm{E}$ & $\mathrm{Su}$ & $2 \pm 0.2$ & $414.8 \pm 12.3$ & $11.2 \pm 2.7$ & $1169 \pm 318^{\mathrm{a}}$ & $1061.5 \pm 304^{\mathrm{a}}$ \\
\hline
\end{tabular}

\section{ACKNOWLEDGEMENTS}

I am specially grateful to Prof. Fábio Rubio Scarano and Prof. Ulrich Lüttge for improvements to the manuscript, and to Marcus Nadruz for the determination of species. Acknowledgments are extensive to Prof. Ricardo Cardoso Vieira, Dr. Harry Luther, Rodrigo Leo, Fernanda Reinert, Sebastião J. Neto and Rosane Arruda. The hospitality and support to the author during field work by the owners of Reserva Botânica das Águas Claras, Cecília Amorim, Mônica Amorim and Gilberto Lafayette de Freitas, was invaluable. This work was partially funded by Fundação Universitária José Bonifácio (FUJB).

\section{RESUMO}

A suculência foliar tem importantes implicações fisiológicas e ecológicas. Usualmente é quantificada pelo índice de Delf (1912) (peso fresco / area foliar) e pela razão peso fresco / peso seco. Estes dois índices são reconsiderados e um novo índice é proposto. Folhas de sombra e sol de aráceas terrestres, hemiepífitas e epífitas foram analisadas. A fórmula de Delf, por não considerar o peso seco das folhas, superestimou a suculência foliar. Como a razão peso fresco / peso seco (pf / ps) não leva em consideração a área das folhas, plantas com a mesma razão pf / ps foram mais de cinco vezes diferentes em relação à area foliar. Este último caso só é possível com a redução da razão superfície / volume e com o aumento da espessura do mesofilo, componentes não considerados pela razão pf / ps. O novo índice 
aqui proposto, que leva em consideração tanto o peso seco das folhas quanto as suas respectivas áreas, mostrou uma alta correlação com a espessura do mesofilo.

\section{REFERENCES}

Araus, J. L. \& Hogan, K. P. (1994), Leaf structure and patterns of photoinhibition in two neotropical palms in clearing and forest understory during the dry season. Am. J. Bot., 81, 726-738.

Coutinho, L. M. (1962), Contribuição ao conhecimento da Ecologia da Mata Pluvial Tropical. Bol. Fac. Cien. Let. USP. Botânica, 18, 1-219.

De Santo, V.; Alfani, A.; Russo, G. \& Fioretto, A. (1983), Relationship between CAM and succulence in some species of Vitaceae and Piperaceae. Bot. Gaz., 144, 342-346.

Delf, E. M. (1912), Transpiration in succulent plants. Ann. Bot., 26, 409-442.

Fahn, A. \& Cutler, D. F. (1992). Xerophytes. Encyclopedia of Plant Anatomy, Gebrüder Borntraeger, Berlin.

Flowers, T. J. (1986), Halophytes. Quart. Rev. Biol., 61, 313-336.

Franco, A. C., Haaj-Kerwer, A., Herzoj, B., Graus, T. E. E., Ball, E., Mattos, E. A.; Scarano, F. R., Barreto, S., Garcia, M. A., Mantovani, A., And Lüttge, U. (1996), The effect of light levels on daily patterns of chlorophyll fluorescence and organic acid accumulation in the tropical CAM tree Clusia hilariana. Trees, 10, 359-365.

Gates, D. M. (1968), Transpiration and leaf temperature. Ann. Rev. Plant Physiol., 19, 211-238.

Haberlandt, G. (1928), Physiological plant anatomy, MacMillian and Co., London.

Hoolbrook, N. M. And Putz, F. E. (1996), From epiphyte to tree: differences transition in growth forms in eight species of hemiepiphytes. Plant, Cell and Environ., 19, 631- 642.

Hopkins, W. G. (1995), Introduction to plant physiology, John Wiley and Sons, New York.

Kaul, R. B. (1977), The role of the multiple epidermis in foliar succulence of Peperomia (Piperaceae). Bot Gaz., 138, 213 - 218.
Kluge, M. \& Ting, I. P. (1978), Crassulacean acid metabolism: analysis of an ecological adaptation, Ecological studies 30, SpringerVerlag, Berlin.

Larcher, W. (1986), Ecofisiologia Vegetal. Editora Pedagógica e Universitária Ltda., São Paulo.

Levitt, J. (1989), Responses of Plants to Environmental Stresses. Academic Press $2^{0}$ ed., New York.

Lüttge, U. E. And Smith, J. A. C. (1984), Structural, biophysical and biochemical aspects of the role of leaves in plant adaptation to salinity and water stress. In Salinity tolerance in plants: strategies for crop improvement, eds. R. C. Staples and G. H. Toenniessen, John Wiley and Sons, New York.

Mantovani, A. (1997), Considerações iniciais sobre a conquista do hábito epifítico pela família Araceae. Msc. Thesis; Federal University of Rio de Janeiro, Rio de Janeiro, Brasil.

Nobel, P. S. (1980), Leaf anatomy and water use efficiency. In - Adaptations of plants to water and high temperature stress, eds. N. C. Turner and D. J. Kramer, Wiley Interscience, New York.

Nobel, P. S., Zaragoza, L. J., and Smith, W. K. (1975), Relation between mesophyll surface area, photosynthetic rate and illumination level during development for leaves of Plectranthus parviflorus Henckel. Plant Physiol., 55, 1067-1070.

Osmond, C. B., Adams Iii, W. W., and Smith, S. D. (1989), Crassulacean acid metabolism. In - Plant Physiological Ecology: fields methods and instrumentation. eds. R. W. Pearcy, J. Ehleringer, H. A. Mooney, P. W. Rundel, Chapman and Hall.

Smith, W. K. (1978), Temperatures of Desert plants: another perspective on the adaptability of leaf size. Science, 201, 614616.

Vieira, R. C. (1995), Anatomia foliar de Baihinia radiata Vell. Em diferentes ambientes. Arq. Biolo. Tecnol., 38, 63-107. 
Walter, H. (1926), Die Anpassugen der Pflanzen an Wassermangel: Das xerophytenproblem in kausal-physiologischer Betrachtung Naturwissenschaft und Landwirtschaft, Heft 9. Freising-münchen: Verlag Verlag. Dr. F. P. Da Herer u. Cie.

Winter, K., Wallace, B. J., Stocker, B. C., And Roksandic, Z. (1983), Crassulacean acid metabolism in australian vascular epiphytes and some related species. Oecologia, 57, 129-141.
Zotz, G. And Winter, K. (1994), A one year study on carbon, water and nutrient relationships in a tropical $\mathrm{C}_{3}$-CAM hemiepiphyte, Clusia uvitana Pittier. New Phytol., 127, 45-60.
Received: November 03, 1997 Revised: June 22, 1998 Accepted: December 04, 1998 